\title{
Pengaruh Kualitas Pembelajaran, Kualitas Tutor dan Motivasi Terhadap Prestasi Belajar Mahasiswa Universitas Terbuka Palembang
}

\author{
Heldiono, Indawan \& Sakdiah Wati \\ Universitas Muhammadiyah Palembang \\ Email: amoheldiono@gmail.com
}

\begin{abstract}
This study aims to determine the effect of learning quality, tutor quality and motivation both jointly and partially on student achievement at the Palembang Open University (Pokjar Pangkalan Lampam - Tulung Selapan. The research approach is quantitative research with associative research type. The population of this study is 186 . students. The sampling method for probability with the Stratified Random Sampling method. The sample of this study was calculated using the Slovin formula with an error rate of $10 \%$, the number of samples was 65 students as respondents. The first sample was tested using the Instrument Validity Test and the Instrument Reliability Test. The analysis model used in this study is multiple linear regression analysis. The regression calculation can be $\mathrm{Y}=-1.649+0.567 \mathrm{X}_{1}+0.351 \mathrm{X}_{2}+0.457 \mathrm{X}_{3}$. Interpretation of the multiple regression equation regarding the influence of the Learning Quality Variables $\left(\mathrm{X}_{1}\right)$, Tutor Quality $\left(\mathrm{X}_{2}\right)$ and Learning Motivation $\left(\mathrm{X}_{3}\right)$, on Student Learning Achievement $(\mathrm{Y})$. The results of the calculation of the three coefficients of the independent variable are positive, this indicates a positive linear relationship (unidirectional), meaning that the quality of learning, quality of tutors and learning motivation, the better, the better the student achievement. Obtained a correlation coefficient (R) of 0.712 , with a level of closeness between variables of 0.712 which is in the interpretation of the correlation value (0.60-0.799) means that the relationship between the two variables is significant and the level of closeness is strong. The coefficient of determination value $\mathrm{R} 2=0.507$, which means that the variables of Learning Quality, Tutor Quality, and Learning Motivation are able to explain the Student Learning Achievement Variables of 0.507 or $50.7 \%$, while the remaining $49.3 \%$ is explained by other factors not examined.
\end{abstract}

Keywords: Learning Quality, Tutor Quality, Motivation and Achievement

\section{Pendahuluan}

Pada hakikatnya, pendidikan memiliki peranan penting dalam mencerdaskan kehidupan bangsa sebagai upaya untuk meningkatkan kesejahteraan masyarakat, serta membangun martabat dalam diri bangsa. Didasari dengan hal tersebut, pasti pemerintah akan berusaha memberikan yang terbaik agar masyarakat bisa mendapatkan pendidikan yang layak dan tentunya secara merata sehingga nantinya mampu bersaing dengan dunia luar. Usaha tersebut ditunjukkan dengan dibuatnya berbagai kebijakan dalam pendidikan merupakan kebijakan yang diharapkan dapat meningkatkan pembelajaran, kualitas dan pemerataan pendidikan di Indonesia sendiri.

Seperti yang kita ketahui di era yang serba cepat ini, manusia dituntut untuk dapat bersaing dan mengikuti arus perkembangan zaman. Saat ini masyarakat dituntut untuk memiliki kemampuan berpikir secara kritis, mandiri, dan tidak mudah menyerah dalam menghadapi tantangan. Masyarakat diharapkan dapat berperan menjadi agen perubahan di dalam kehidupan masyarakat sendiri. Untuk itu perlu adanya upaya bagi suatu individu agar dapat mengembangkan kemampuannya dalam berinteraksi dengan masyarakat luas. 
Namun terkadang pendidikan sekolah atau formal saja tidak cukup bagi kita untuk mendapat semua pengetahuan secara lengkap. Disinilah pendidikan belajar mandiri melalui Unit Program Belajar Jarak Jauh berperan.

Dalam konsep belajar mandiri mengandung pengertian mahasiswa harus dapat memotivasi dirinya untuk belajar secara berkala dan rutin, artinya mahasiswa tidak belajar semalam suntuk ketika besuk pagi akan ujian. Belajar mandiri sangat ditentukan oleh ketepatan dan kemampuan mahasiswa dalam memahami isi materi modul. Untuk itu mahasiswa UT harus selalu mendisiplinkan diri, dan punya kemauan/inisiatif, serta motivasi belajar yang tinggi (Isman \& Djoko, 2014).

Dari hasil Pengamatan, pembelajaran di UPBJJ-UT Palembang, masih menekankan pada proses pemindahan informasi tutor kepada siswa yang menggunakan media papan tulis, buku cetak, dan LKS. Peran tutor masih sangat dominan. Tutor menyusun RAT-SAT pembelajaran, siswa tinggal menerima rancangan SAT pembelajaran dan informasi yang diberikan oleh tutor. Tutor menyampaikan materi pelajaran menggunakan media konvensional yaitu buku cetak, LKS, dan papan tulis.

Pembelajaran merupakan proses kegiatan belajar mengajar yang juga berperan dalam menentukan keberhasilan belajar siswa. Dari proses pembelajaran itu akan terjadi sebuah kegiatan timbal balik antara guru dengan siswa untuk menuju tujuan yang lebih baik. Istilah pembelajaran merupakan istilah yang digunakan untuk menunjukkan adanya kegiatan guru dan siswa. Sebelumnya kita menggunakan istilah proses belajar mengajar dan pengajaran. Istilah pembelajaran merupakan terjemahan dari kata instruction. Kondisi saat ini telah banyak orang memilih istilah pembelajaran karena mengacu pada segala kegiatan yang berpengaruh langsung terhadap proses belajar, sedangkan pengajaran hanya pada konteks tatap muka guru-siswa di dalam kelas (Nazarudin Rahman, 2015).

Kegiatan belajar mengajar adalah suatu kondisi yang dengan sengaja diciptakan. Guru atau tutorlah yang menciptakannya guna membelajarkan mahasiswa atau peserta didik. Tutor yang mengajar dan peserta didik yang belajar. Perpaduan dan kedua unsur manusiawi ini lahirlah interaksi edukatif dengan memanfaatkan bahan sebagai mediumnya. Di sana semua komponen pengajaran diperankan secara optimal guna mencapai tujuan pengajaran yang telah ditetapkan sebelum pangajaran dilaksanakan (Afandi, et, al. 2013).

Sedangkan Depdiknas (2004) mengemukakan bahwa kualitas pembelajaran dipengaruhi oleh masukan instrumental seperti pendidik, kurikulum/bahan ajar, iklim pembelajaran, media, fasilitas, dan materi. Dari segi pendidik, kualitas dapat dilihat dari seberapa optimal guru/tutor mampu memfasilitasi belajar. Sementara dari segi kurikulum dapat dilihat dari seberapa luwes dan relevan kurikulum dan bahan belajar mampu menyediakan stimulus dan fasilitas belajar yang sesuai tingkat penggolongan.

Kualitas pembelajaran merupakan tingkat keefektifitasan proses pembelajaran dalam tutorial ditentukan oleh tutor-tutor yang berkualitas. Seorang tutor dikatakan berkualitas apabila mampu merancang Rancangan Aktivitas Tutorial (RAT) dan Satuan Aktivitas Tutorial (SAT) dengan baik, mulai dari merancang kompetensi khusus (KK) yang sesuai dengan kompetensi umum (KU) yang akan dicapai mahasiswa setelah tutorial, mampu menetapkan pokok dan sub pokok bahasan sesuai dengan KK. Tutor yang berkualitas diharapkan juga mampu memilih model tutorial sesuai dengan KK, karakteristik mata kuliah, mahasiswa, dan alokasi waktu. 
Dalam interaksi itu, mahasiswa yang seharusnya lebih aktif dibandingkan dengan tutor. Dalam kegiatan belajar mengajar harus terjadi komunikasi dua arah antara tutor dengan mahasiswa agar suasana pembelajaran kondusif. Tidak lagi teacher center melainkan student center sehingga proses belajar mengajar akan terarah dalam mencapai tujuan pembelajaran. Paradigma selama ini pembelajaran yang dilakukan hanya berpusat dengan guru (teacher center) sebagai sumber belajar, bukan berpusat pada siswa (student center) sehingga tutor akan mendominasi proses pembelajaran di dalam kelas sedangkan siswanya hanya pasif. Peran tutor sebagai seorang fasilitator belum terlihat dalam proses pembelajaran. Selayaknya tutor harus mampu menguasai tiga kompetensi dasar yang diharapkan akan terjalin komunikasi dua arah sehingga tujuan pembelajaran dapat tercapai. Mengacu pada PP No. 19 tahun 2005, Tutor merupakan ujung tombak kegiatan pembelajaran karena berhadapan langsung dengan warga belajar. Tutor hendaknya memiliki kualifikasi yang dipersyaratkan dan standart kompetensi minimal sebagai tenaga pendidik, yakni berkualifikasi minimal S1 atau D IV. Dengan tenaga pendidik yang berkualitas dapat meningkatkan prestasi belajar mahasiswa pokjar Pangkalan Lampam - Tulung Selapan. Tujuan penelitian ini untuk mengetahui seberapa besar pengaruh kualitas pembelajaran, kualitas tutor dan motivasi terhadap prestasi belajar mahasiswa Program S.1 PGSD dan S.1 Ilmu Pemerintahan Universitas Terbuka Palembang

\section{Tinjauan Literatur}

\subsection{Kualitas Pembelajaran}

Kualitas dapat dimaknai dengan istilah mutu atau juga keefektifan. Pengertian kualitas secara garis besar berorientasi kepada memberi kepuasan kepada pelanggan yang menjadi tujuan organisasi, pelanggan ditempatkan sebagai raja. Di dalam Kamus Besar Bahasa Indonesia dalam jurnal Dwi Puryanto (2015), bahwa kualitas adalah ukuran baik buruk, mutu, taraf, kadar, atau derajat dari kecerdasan, kepandaian dan sebagainya. Sedangkan menurut Nana Sudjana, pengertian secara umum dapat diartikan suatu gambaran yang menjelaskan mengenai baik buruk hasil yang dicapai para siswa dalam proses pendidikan yang dilaksanakan. Sedangkan pembelajaran merupakan proses kegiatan belajar mengajar yang juga berperan dalam menentukan keberhasilan belajar siswa. Dari proses pembelajaran itu akan terjadi sebuah kegiatan timbal balik antara guru dengan siswa untuk menuju tujuan yang lebih baik. Istilah pembelajaran merupakan istilah yang digunakan untuk menunjukkan adanya kegiatan guru dan siswa. Sebelumnya kita menggunakan istilah proses belajar mengajar dan pengajaran. Istilah pembelajaran merupakan terjemahan dari kata instruction. Kondisi saat ini telah banyak orang memilih istilah pembelajaran karena mengacu pada segala kegiatan yang berpengaruh langsung terhadap proses belajar, sedangkan pengajaran hanya pada konteks tatap muka guru-siswa di dalam kelas (Nazarudin Rahman, 2015).

\section{Indikator Kualitas Pembelajaran}

Indikator-indikator dari kualitas pembelajaran dalam penelitian ini adalah :

1) Perilaku atau aktivitas siswa

2) Iklim Pembelajaran

3) Materi Pembelajaran

4) Media Pembelajaran

5) Metode Pembelajaran 


\subsection{Kualitas Tutor}

Dasar yuridis yang bersinggungan langsung dengan kualitas pendidikan adalah Peraturan Pemerintah RI. no. 19 Tahun 2005 tentang standar nasional pendidikan. Peraturan ini memuat 97 pasal yang mengatur tentang Standar Isi, Standar Proses, Standar Kompetensi Lulusan, Standar Pendidikan dan Tenaga Pendidikan, Standar Sarana dan Prasarana, Standar Pengelolaan, Standar Pembiayaan, dan Standar Penilaian Pendidikan. Menurut Peraturan Pemerintah ini yang dimaksud dengan standar nasional pendidikan adalah kriteria minimal tentang sistem pendidikan di seluruh wilayah hukum Negara Kesatuan Republik Indonesia. Secara rasional, penyelenggaran pendidikan yang berkualitas adalah pendidikan yang memenuhi keseluruhan standar atau mungkin melampauinya.Sedangkan menurut Dedy Sugono (2008), tutor adalah orang yang memberi pelajaran (bimbingan) kepada seseorang atau sejumlah kecil peserta didik dalam pembelajaran. Menurut Raharjo (2005) tutor adalah mitra dan pembimbing warga belajar yang menempatkan dirinya sebagai sumber belajar, yang berarti pula pengelolaan pembelajaran berpusat pada warga belajar. Dengan dimikian dapat dikatakan bahwa tutor merupakan orang yang berinteraksi secara langsung dalam proses pembelajaran (dalam jurnal Zalma \& Maria, 2020). Tutor adalah seseorang yang kompeten dan diberi tugas memfasilitasi proses belajar mahasiswa. Tutor ada yang berasal dari perguruan tinggi konvensional yang diistilahkan dengan tutor dari Padang, dan ada lagi tutor yang diambil dari daerah yang dinamakan tutor daerah. Tutor daerah dimanfaatkan untuk mengisi kekurangan tutor pada pokjar-pokjar tertentu. Sebelum tutor ditugaskan, mereka wajib mengikuti penyeleksian dan Pelatihan Akreditasi Tutor Universitas Terbuka (PAT-UT).

Dari berbagai uraian di atas, dapat disimpulkan bahwa indikator-indikator dari kualitas tutor dalam penelitian ini adalah :

1) Kompetensi Personal

2) Kompetensi Sosial

3) Kompetensi Profesional

4) Kompetensi Pedagogik

Motivasi Belajar Mahasiswa

Menurut Sardiman (2016) motivasi adalah perubahan energi dalam diri seseorang yang ditandai dengan munculnya "felling" dan didahului dengan tanggapan terhadap adanya tujuan. Menurut Mulyasa (2013) motivasi adalah tenaga pendorong atau penarik yang menyebabkan adanya tingkah laku ke arah suatu tujuan tertentu. Peserta didik akan bersungguh-sungguh karena memiliki motivasi yang tinggi. Seseorang akan belajar bila ada faktor pendorongnya yang disebut motivasi. Dimyati dan Mudjiono (2012) mengutip pendapat Koeswara mengatakan bahwa siswa belajar karena didorong kekuatan mental, kekuatan mental itu berupa keinginan dan perhatian, kemauan, cita-cita di dalam diri seorang terkadang adanya keinginan yang mengaktifkan, menggerakkan, menyalurkan dan mengarahkan sikap dan perilaku individu dalam belajar. Jadi dapat disimpulkan bahwa motivasi belajar adalah keseluruhan daya penggerak didalam diri mahasiswa yang menimbulkan kegiatan belajar menjamin kelangsungan dan memberikan arah pada kegiatan belajar sehingga tujuan yang dikehendaki dapat tercapai. Motivasi itu meliputi: rasa ingin tahu, merasa adanya kesesuaian dengan kebutuhan,adanya kepercayaan diri akan kemampuannya serta adanya kepuasan tersendiri bila mampu menyelesaikan tugas dengan baik, Dalam belajar, motivasi / dorongan merupakan kekuatan mental untuk melakukan kegiatan dalam rangka pemenuhan harapan dalam hal ini adalah pencapaian 
tujuan.

\subsection{Indikator-indikator Motivasi}

Menurut Sardiman (2016) motivasi pada diri seseorang itu memiliki ciri-ciri :

1) Tekun menghadapi tugas

2) Ulet menghadapi kesulitan (tidak lekas putus asa)

3) Menunjukkan minat terhadap bermacam-macam masalah

4) Lebih senang bekerja mandiri

5) Tidak cepat bosan terhadap tugas-tugas yang rutin

6) Dapat mempertahankan pendapatnya

7) Tidak cepat menyerah terhadap hal yang diyakini

8) Senang mencari dan memecahkan masalah soal-soal.

Apabila mahasiswa mempunyai ciri-ciri tersebut, berarti mahasiswa mempunyai motivasi yang cukup kuat. Kegiatan belajar mengajar akan berhasil baik jika mahasiswa memiliki motivasi untuk belajar, tekun dalam menghadapi tugas, senang memecahkan soal-soal, ulet dalam mengatasi kesulitan belajar. Dari berbagai uraian di atas, dapat disimpulkan bahwa indikator-indikator dari motivasi dalam penelitian ini adalah:

a) tekun dalam menghadapi tugas

b) adanya ketertarikan dengan perkuliahan

c) senang memecahkan soal-soal dan latihan

d) ulet dalam mengatasi kesulitan belajar

2.4 Prestasi Belajar Mahasiswa

Menurut Aziz dalam jurnal tarbiyah (2018), mendefinisikan bahwa prestasi belajar merupakan suatu proses kegiatan yang dilakukan oleh seseorang yang menghasilkan suatu perubahan tingkah laku yang baru sebagai hasil interaksi dengan lingkungannya. Kata kunci dari pengertian belajar adalah "perubahan" dalam diri individu yang belajar. Perubahan yang dikehendaki oleh pengertian belajar. Karena belajar merupakan suatu proses usaha, maka di dalamnya terdapat tahapan-tahapan yang harus dilalui untuk sampai kepada hasil belajar itu sendiri yaitu 1) aspek kognitif; 2) afektif; dan 3) psikomotor. Menurut Siti Maesaroh dalam jurnalnya (2013) mendefinisikan bahwa prestasi belajar adalah merupakan hasil daripada aktivitas belajar atau hasil dari usaha, latihan dan pengalaman yanag dilakukan oleh seseorang, dimana prestasi tersebut tidak akan lepas dari pengaruh faktor luar diri siswa.

\subsection{Indikator Prestasi Akademik Mahasiswa.}

Dwipurwani (2012) mengatakan bahwa prestasi mahasiswa dapat dilihat dari IPK (Indeks Prestasi Kumulatif) yang mengukur mahasiswa secara akademik. Nilai IPK dipengaruhi oleh berbagai hal sebagai berikut :

1). Kualitas tenaga pengajar, yang diukur melalui tingkat pendidikan formal yang ditamatkan.

2). Penguasaan metode mengajar

3). Penguasaan materi yang diajarkan.

\subsection{Kerangka Pemikiran}

Berdasarkan pemaparan pada pada latar belakang, rumusan masalah, tujuan penelitian, kajian empiris maupun teoritis, maka secara konseptual variabel kualitas pembelajaran, kualitas tutor dan motivasi dalam penelitian ini mengadopsi pendapat yang dikemukakan 
oleh Sugiyono (2015: 92) bahwa kerangka fikir merupakan sintesa tentang hubungan antar variabel yang disusun dari berbagai teori yang telah dideskripsikan. Berdasarkan teori-teori yang telah dideskripsikan tersebut, selanjutnya dianalisis secara kritis dan sistematis, sehingga menghasilkan sintesa tentang hubungan antar variabel yang diteliti. Seorang peneliti harus menguasasi teori-teori ilmiah sebagai dasar bagi argumentasi dalam menyusun kerangka pemikiran yang membuahkan hipotesis. Sintesa tentang hubungan variabel tersebut, selajutnya digunakan untuk merumuskan hipotesis.

Dengan demikian, untuk lebih jelasnya kerangka konseptual pada penelitian ini dapat dilihat pada gambar. 1 di bawah ini

Gambar 1. Kerangka Konseptual Penelitian



Sumber : Pemikiran Peneliti berdasar Teori, 2020

\section{Metodelogi Penelitian}

Pendekatan penelitian ini merupakan penelitian kuantitatif dengan jenis penelitian Asosiatif. Penelitian ini menggunakan tiga variabel yaitu Kualitas Pembelajaran, Kualitas Tutor, Motivasi terhadap Prestasi Belajar Mahasiswa.

Variabel merupakan atribut sekaligus objek yang menjadi titik perhatian suatu penelitian. Komponen dimaksud penting dalam menarik kesimpulan atau inferensi suatu penelitian. Selain itu kriteria atau syarat suatu variabel yang baik dalam pengembangannya harus dipahami dan dimengerti dengan baik sehingga menjadi dasar identifikasi dan pengembangan variabel-variabel penelitian (Sandu dan Ali, 2015: 50). Variabel pada penelitian ini adalah sebagai berikut : Kualitas Pembelajaran, Kualitas Tutor, Motivasi dan Prestasi Belajar Mahasiswa.

Tabel 1. Definisi Operasional 


\begin{tabular}{|c|c|c|c|c|}
\hline Variabel & Dimensi & Indikator & Skala & $\begin{array}{c}\text { Item } \\
\text { Kuesioner }\end{array}$ \\
\hline $\begin{array}{l}\text { Prestasi } \\
\text { Belajar (Y) }\end{array}$ & $\begin{array}{l}\text { Prestasi belajar merupakan hasil } \\
\text { belajar seseorang yang diperoleh } \\
\text { dari suatu proses pembelajaran } \\
\text { dan hasil belajar yang } \\
\text { diperolehnya merupakan hasil } \\
\text { dari evaluasi atau penilaian yang } \\
\text { dilakukan oleh tutor kepada } \\
\text { mahasiswanya }\end{array}$ & $\begin{array}{l}\text { Nilai Prestasi Belajar/ } \\
\text { Nilai IPK } \\
\text { 1. Kualitas tenaga } \\
\text { pengajar. } \\
\text { 2. Penguasaan metode } \\
\text { mengajar } \\
\text { 3. Penguasaan materi } \\
\text { yang diajarkan. }\end{array}$ & Ordinal & $\begin{array}{l}1,2 \\
3,4 \\
3,6\end{array}$ \\
\hline $\begin{array}{l}\text { Kualitas } \\
\text { Pembelajaran } \\
\left(\mathbf{X}_{1}\right)\end{array}$ & $\begin{array}{l}\text { Kualitas pembelajaran adalah } \\
\text { tingkat pencapaian tujuan } \\
\text { pembelajaran dalam kegiatan } \\
\text { pembelajaran yang di dalamnya } \\
\text { dipengaruhi oleh berbagai faktor } \\
\text { salah satunya kemampuan guru } \\
\text { dalam mengelola pembelajaran, di } \\
\text { mana pencapaian tujuan } \\
\text { pembelajaran berupa peningkatan } \\
\text { aktivitas siswa, pengetahuan, } \\
\text { keterampilan dan sikap yang dapat } \\
\text { dilihat dari peningkatan hasil } \\
\text { belajar dalam proses } \\
\text { pembelajaran. }\end{array}$ & 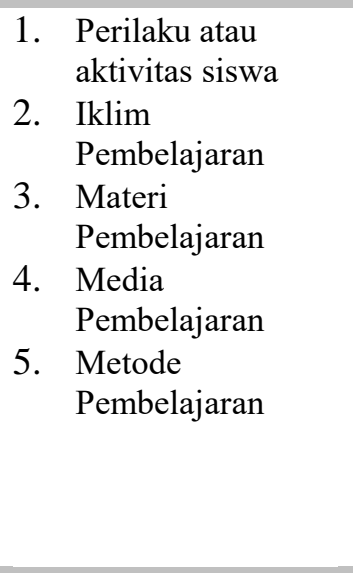 & Ordinal & $\begin{array}{l}1 \text { s.d } 4 \\
5 \text { s.d } 6 \\
9 \text { s.d } 12 \\
13 \text { s.d } 14 \\
17 \text { s.d } 18\end{array}$ \\
\hline $\begin{array}{l}\text { Kualitas } \\
\text { Tutor }\left(\mathbf{X}_{2}\right)\end{array}$ & $\begin{array}{l}\text { Seorang tutor yang berkualitas } \\
\text { adalah tutor yang mampu } \\
\text { mempersiapkan rencana kegiatan } \\
\text { yang akan dilakukan dalam satu } \\
\text { semester, sekaligus } \\
\text { mempersiapkan rencana kegiatan } \\
\text { apa saja yang harus dilakukan } \\
\text { untuk setiap kali pertemuan } \\
\text { tutorial. }\end{array}$ & $\begin{array}{ll}\text { 1. } & \text { Kompetensi } \\
\text { 2ersonal } \\
\text { 2. Kompetensi Sosial } \\
\text { 3. Kompetensi } \\
\text { Profesional } \\
\text { 4. } & \text { Kompetensi } \\
& \text { Pedagogik }\end{array}$ & Ordinal & $\begin{array}{l}1 \text { s.d } 5 \\
6 \text { s.d } 10 \\
11 \text { s.d } 15 \\
16 \text { s.d } 20\end{array}$ \\
\hline Motivasi $\left(\mathbf{X}_{3}\right)$ & $\begin{array}{l}\text { daya penggerak didalam diri } \\
\text { mahasiswa UT yang } \\
\text { menimbulkan kegiatan belajar } \\
\text { menjamin kelangsungan dan } \\
\text { memberikan arah pada kegiatan } \\
\text { belajar sehingga tujuan yang } \\
\text { dikehendaki dapat tercapai. }\end{array}$ & $\begin{array}{l}\text { 1. Tekun dalam } \\
\text { menghadapi tugas } \\
\text { 2. Ketertarikan } \\
\text { dengan perkuliahan } \\
\text { 3. Senang } \\
\text { memecahkan soal- } \\
\text { soal dan latihan } \\
\text { 4. Ulet dalam } \\
\text { mengatasi kesulitan } \\
\text { belajar }\end{array}$ & Ordinal & $\begin{array}{l}1 \text { s.d } 5 \\
6 \text { s.d } 10 \\
11 \text { s.d } 15 \\
16 \text { s.d } 20\end{array}$ \\
\hline
\end{tabular}

Sumber: Hasil Pemikiran Peneleti berdasarkan Teori, 2020

Teknik pengambilan sampel yang digunakan adalah Teknik Probability Sampling yaitu dimana setiap anggota populasi mempunyai peluang sama untuk dipilih menjadi anggota sampel dengan cara Stratified Random Sampling (Husein, 2019). Responden sampel dalam penelitian ini berjumlah 65 mahasiswa. Kuesioner atau angket sebagai metode 
yang dipilih untuk mengumpulkan data dengan lima pilihan jawaban yakni Sangat Tidak Setuju, Tidak Setuju, Netral, Setuju, Sangat Setuju. Dengan tujuan untuk mendapatkan jawaban-jawaban yang akan digunakan sebagai data dalam penelitian ini.

Uji validitas berguna untuk mengetahui apakah ada pertanyaan/pernyataan pada kuesioner yang harus dihapus/diganti karena tidak mengukur yang hendak diukur (Husein, 2019). Uji reliabilitas berguna untuk menetapkan apakah instrument kuesioner dinyatakan reliabel, yaitu dapat digunakan secara konsisten. Untuk uji reliabilitas untuk alternatif jawaban lebih dari dua (misalnya skala 1-5, 1-7 dan lain-lain), gunakan uji Cronbach's Alpha. Dalam penelitian ini digunakan analisis regresi linier berganda dengan alasan ingin mengetahui seberapa besar pengaruh variabel independen (kualitas pembelajaran, kualitas tutor dan motivasi) dan prestasi belajar (variabel dependen) baik secara parsial maupun simultan. Dalam menguji hipotesis digunakan Uji F yang bertujuan untuk melihat signifikan tidaknya pengaruh variabel bebas secara bersama-sama (simultan) terhadap variaber terikat.dan Uji t yang digunakan untuk mengetahui signifikan tidaknya pengaruh masing-masing variabel secara individual (parsial) terhadap sebuah variabel terikat.

\section{Hasil dan Pembahasan}

\subsection{Hasil uji validitas}

a. Variabel Prestasi Belajar Mahasiswa (Y).

didapat hasil uji validitas akan variabel Variabel Prestasi Belajar Mahasiswa ( $\left.\mathrm{Y}_{1}\right)$ dimana tidak terdapat item-item yang memiliki nilai corrected Item-Total Correlation $>0,3610$, sehingga semua item dalam variable Prestasi Belajar Mahasiswa $\left(\mathrm{Y}_{1}\right)$ ini dapat dipergunakan, sehingga pernyataan untuk variable Prestasi Belajar Mahasiswa $\left(\mathrm{Y}_{1}\right)$ terdiri dari 6 item, yang terdiri dari : $\mathrm{Y}_{1.1}, \mathrm{Y}_{1.2}, \mathrm{Y}_{1.3}, \mathrm{Y}_{1.4}, \mathrm{Y}_{1.5}$, Y1.6.

b. Variabel Kualitas Pembelajaran $\left(\mathrm{X}_{1}\right)$.

Didapat hasil uji validitas akan variabel Variabel Kualitas Pembelajaran $\left(\mathrm{X}_{1}\right)$ dimana terdapat item $\mathrm{X}_{1.5}$ yang memiliki nilai corrected Item-Total Correlation $<0,3610$, sehingga semua item ini harus di uji validasi kembali. Dari hasil eliminasi pengujian validitas terhadap item-item pada Variabel Kualitas Pembelajaran $\left(\mathrm{X}_{1}\right)$ didapat hasil uji nilai hitung corrected Item-Total Correlation $>0,3610$ seluruh item dinyatakan valid kecuali item $\mathrm{X}_{1.5}$ tidak valid dan tidak dapat digunakan untuk proses estimasi selanjutnya, sedangkan pernyataan untuk Variabel Kualitas Pembelajaran $\left(\mathrm{X}_{1}\right)$ terdiri dari 17 item, yaitu : $\mathrm{X}_{1.1}, \mathrm{X}_{1.2}, \mathrm{X}_{1.4}, \mathrm{X}_{1.6}, \mathrm{X}_{1.7}, \mathrm{X}_{1.8}, \mathrm{X}_{1.9}, \mathrm{X}_{1.10}, \mathrm{X}_{1.11}, \mathrm{X}_{1.12}, \mathrm{X}_{1.13}, \mathrm{X}_{1.14}$ $\mathrm{X}_{1.15}, \mathrm{X}_{1.16}, \mathrm{X}_{1.17}, \mathrm{X}_{1.18}$. dinyatakan valid dan dapat digunakan untuk proses estimasi selanjutnya.

c. Variabel Kualitas Tutor $\left(\mathrm{X}_{2}\right)$

Dari hasil pengujian validitas terhadap item-item pada Variable Kualitas Tutor $\left(\mathrm{X}_{2}\right)$ seperti terlihat pada Tabel diatas, didapat hasil uji nilai hitung corrected Item-Total Correlation $>0,3610$ sehingga seluruh item dinyatakan valid, sehingga pernyataan untuk Variabel Kualitas Tutor $\left(\mathrm{X}_{2}\right)$ terdiri dari 20 item, yaitu : $\mathrm{X}_{2.1}, \mathrm{X}_{2.2}, \mathrm{X}_{2.3}, \mathrm{X}_{2.4}, \mathrm{X}_{2.5}, \mathrm{X}_{2.6}$, $\mathrm{X}_{2.7}, \mathrm{X}_{2.8}, \mathrm{X}_{2.9}, \mathrm{X}_{2.10}, \mathrm{X}_{2.11}, \mathrm{X}_{2.12}, \mathrm{X}_{2.13}, \mathrm{X}_{2.14}, \mathrm{X}_{2.15}, \mathrm{X}_{2.16}, \mathrm{X}_{2.17}, \mathrm{X}_{2.18}, \mathrm{X}_{2.19}, \mathrm{X}_{2.20}$. 
d. Variabel Motivasi Belajar $\left(\mathrm{X}_{3}\right)$.

Peneliti melakukan uji validitas item-item pernyataan variabel motivasi belajar yang diberikan kepada responden. Data yang diperoleh untuk melihat dan menganalisis fenomena di lapangan. Dari hasil pengujian validitas terhadap item-item pada variable Variabel Motivasi Belajar $\left(\mathrm{X}_{3}\right)$ seperti terlihat pada Tabel diatas, didapat hasil uji nilai hitung corrected Item-Total Correlation $>0,3610$ sehingga seluruh item dinyatakan valid, sehingga pernyataan untuk Variabel Motivasi Belajar $\left(X_{3}\right)$ terdiri dari 20 item, yaitu : $\mathrm{X}_{3.1}, \mathrm{X}_{3.2}, \mathrm{X}_{3.3}, \mathrm{X}_{3.4}, \mathrm{X}_{3.5}, \mathrm{X}_{3.6}, \mathrm{X}_{3.7}, \mathrm{X}_{3.8}, \mathrm{X}_{3.9}, \mathrm{X}_{3.10}, \mathrm{X}_{3.11}, \mathrm{X}_{3.12}, \mathrm{X}_{3.13}, \mathrm{X}_{3.14}, \mathrm{X}_{3.15}, \mathrm{X}_{3.16}$, $\mathrm{X}_{3.17}, \mathrm{X}_{3.18}, \mathrm{X}_{3.19}, \mathrm{X}_{3.20}$ dapat digunakan dalam proses estimasi selanjutnya.

\subsection{Hasil uji reliabilitas}

Uji reliabilitas digunakan untuk mengukur konsistensi konstruk atau variabel penelitian. Mengukur uji reliabilitas dilakukan dengan menggunakan uji statistik Cronbach Alpha. Suatu konstruk atau variabel dikatakan reliabel sedang jika memberikan nilai koefisien Cronbach's Alpha lebih besar daripada 0,60. Hasil uji reliabilitas dalam penelitian ini dapat dilihat sebagai berikut:

Tabel 2. Uji Reliabilitas Variabel X dan Y

\begin{tabular}{|c|c|c|c|}
\hline Variabel & & $\begin{array}{c}\text { Cronbach's } \\
\text { Alpha }\end{array}$ & $\mathbf{N}$ of Items \\
\hline $\begin{array}{l}\text { Kualitas Pembelajaran } \\
\text { eliminasi }\end{array}$ & $\left(\mathbf{X}_{1}\right)$ sebelum & .937 & 19 \\
\hline $\begin{array}{l}\text { Kualitas Pembelajaran } \\
\text { eliminasi }\end{array}$ & $\left(\mathbf{X}_{1}\right)$ setelah & .944 & 16 \\
\hline Kualitas Tutor $\left(\mathrm{X}_{2}\right)$ & & .951 & 21 \\
\hline Motivasi Belajar $\left(\mathrm{X}_{3}\right)$ & & .948 & 21 \\
\hline Prestasi Belajar (Y) & & .944 & 7 \\
\hline
\end{tabular}

Sumber: Data primer yang diolah, 2020

Hasil pengujian reliabilitas pada Tabel di atas menunjukkan bahwa nilai koefisien Cronbach's Alpha dari variabel-variabel yang diteliti menunjukkan hasil yang beragam dan variabel menghasilkan nilai Cronbach's Alpha lebih besar dari 0,60. Dengan demikian dapat disimpulkan bahwa alat ukur yang digunakan dalam penelitian ini adalah reliabel.

\subsection{Hasil Koefisien Regresi Berganda}

Dengan tujuan untuk mengetahui seberapa besarpengaruh variabel independen (kualitas pembelajaran, kualitas tutor, motivasi), dan variabel dependen (prestasi belajar) baik secara parsial maupun simultan. Atas dasar hasil hitung regresi linier sederhana tersebut diperoleh, nilai konstanta sebesar -1,649 dan nilai koefisien Variabel Kualitas Pembelajaran $\left(\mathrm{X}_{1}\right)$ sebesar 0,567, Kualitas Tutor $\left(\mathrm{X}_{2}\right)$ sebesar 0,351 dan Motivasi Belajar $\left(\mathrm{X}_{3}\right)$ sebesar 0,457 , jadi persamaan regresianya adalah $\mathrm{Y}=-1,649+0,567 \mathrm{X}_{1}+0,351 \mathrm{X}_{2}+$ $0,457 \mathrm{X}_{3}$. Konstanta negatif umumnya terjadi jika ada rentang yang cukup jauh antara $\mathrm{X}$ 
(variabel independen) dan Y (variabel dependen) Karena dasarnya regresi digunakan memprediksi $\mathrm{Y}$ berdasarkan nilai perubahan $\mathrm{X}$, maka harusnya yang menjadi perhatian adalah $\mathrm{X}$ nya (slope), bukan nilai konstanta.

Interprestasi dari persamaan regresi berganda dapat dijelaskan yaitu jika Variabel Kualitas Pembelajaran $\left(\mathrm{X}_{1}\right)$, sebesar $\mathbf{0 , 5 6 7}$ berslope positif, Maka bisa dinyatakan bahwa satu skor kenaikan pada variabel $\mathrm{X}_{1}$ bisa memberikan kenaikan atau pengaruh sebesar 0,567 pada variabel Y. Variabel Kualitas Tutor $\left(\mathrm{X}_{2}\right)$, sebesar $\mathbf{0 , 3 5 1}$ berslope positif, Maka bisa dinyatakan bahwa satu skor kenaikan pada variabel $\mathrm{X}_{2}$ bisa memberikan kenaikan atau pengaruh sebesar 0,351 pada variabel Y. Variabel motivasi $\left(\mathrm{X}_{3}\right)$, sebesar $\mathbf{0 , 4 5 7}$ berslope positif, Maka bisa dinyatakan bahwa satu skor kenaikan pada variabel $\mathrm{X}_{3}$ bisa memberikan kenaikan atau pengaruh sebesar 0,457 pada variabel Y. Berikut hasil output regresi linier sederhana

Tabel 3. Hasil Koefisien Regresi Berganda

\begin{tabular}{|c|c|c|c|c|c|c|c|c|}
\hline \multicolumn{9}{|c|}{ Coefficients $^{\mathrm{a}}$} \\
\hline \multirow[b]{2}{*}{ Mod } & & \multicolumn{2}{|c|}{$\begin{array}{l}\text { Unstandardized } \\
\text { Coefficients }\end{array}$} & \multirow{2}{*}{$\begin{array}{c}\text { Standardized } \\
\text { Coefficients }\end{array}$} & \multirow[b]{2}{*}{$t$} & \multirow[b]{2}{*}{ Sig. } & \multicolumn{2}{|c|}{ Collinearity Statistics } \\
\hline & & B & Std. Error & & & & Tolerance & VIF \\
\hline & (Constant) & -1.649 & .771 & & -2.138 & .037 & & \\
\hline & Kualitas Pembelajaran & .567 & .102 & .532 & 5.542 & .000 & .875 & 1.143 \\
\hline & Kualitas Tutor & 351 & .114 & 296 & 3.077 & .003 & 875 & 1.143 \\
\hline & Motivasi Belajar & .457 & .143 & .291 & 3.203 & .002 & .980 & 1.021 \\
\hline
\end{tabular}

a. Dependent Variable: Prestasi Belajar Mahasiswa

\subsection{Hasil Pengujian Korelasi $(R)$ dan Koefisien Determinasi $\left(R^{2}\right)$}

Analisis korelasi adalah untuk menentukan seberapa erat hubungan antara satu variabel dengan variabel lainnya. Koefisien Determinasi digunakan dalam kaitannya dengan penggunaan analisis korelasi untuk melihat besar kecilnya besaran kontribusi atas variabel bebas menjelaskan variabel terikat. dilihat hasil dari pengujian $\mathrm{R}$ dan $\mathrm{R}^{2}$.

Tabel 4. Output Korelasi (R) dan Koefisien Determinasi (R2)

Model Summary ${ }^{b}$

\begin{tabular}{|l|r|r|r|r|r|}
\hline Model & R & R Square & $\begin{array}{c}\text { Adjusted } \\
\text { R Square }\end{array}$ & $\begin{array}{c}\text { Std. Error of } \\
\text { the Estimate }\end{array}$ & $\begin{array}{c}\text { Durbin- } \\
\text { Watson }\end{array}$ \\
\hline 1 & $.712^{\mathrm{a}}$ & .507 & .483 & .756259 & 2.184 \\
\hline
\end{tabular}

a. Predictors: (Constant), Motivasi Belajar, Kualitas Tutor, Kualitas Pembelajaran

b. Dependent Variable: Prestasi Belajar Mahasiswa

Hasil pengujian menunjukkan koefisien korelasi (R) sebesar 0,712. Dari hasil yang didapat dengan mengkaitkan hasil koefisien korelasi dengan tingkat keeratan antara variabel sebesar 0,712 yang berada pada interpretasi nilai korelasi $(0,60-0,799)$ artinya bahwa hubungan kedua variabel signifikan dan tingkat keeratannya Kuat. Sementara untuk nilai Koefisien Determinasi $\mathrm{R}^{2}=0,507$ yang berarti bahwa Variabel Kualitas Pembelajaran $\left(\mathrm{X}_{1}\right)$, Kualitas Tutor $\left(\mathrm{X}_{2}\right)$, dan Motivasi Belajar $\left(\mathrm{X}_{3}\right)$ mampu menjelaskan Variabel Prestasi Belajar Mahasiswa (Y) sebesar 0,507 atau 50,7\%, sedangkan sisanya sebesar 49,3\% dijelaskan oleh faktor lain yang tidak diteliti. Dikarenakan berdasarkan 
tabel 4.20, nilai koefisien determinasi yang dinilai sedang yaitu sebesar 50,7\%, maka dalam hal ini peneliti memberikan rekomendasi kepada peneliti yang lain untuk melakukan penelitian serupa dengan menambahkan variabel penelitian seperti manajemen kelas, kurikulum, suasana belajar, kualitas guru, kompetensi guru guna menyempurnakan penelitian ini dengan variabel lainnya diluar variabel yang sedang peneliti gunakan saat ini. Dimana data interprestasi korelasinya sebagai berikut :

Tabel 5. Pedoman Untuk Memberikan Interprestasi Koefisien Korelasi

\begin{tabular}{cc}
\hline Interval koefisien & Tingkat hubungan \\
\hline $\mathbf{0 , 0 0 - 0 , 1 9 9}$ & Sangat Rendah \\
$\mathbf{0 , 2 0 - 0 , 3 9 9}$ & Rendah \\
$\mathbf{0 , 4 0 - 0 , 5 9 9}$ & Sedang \\
$\mathbf{0 , 6 0 - 0 , 7 9 9}$ & Kuat \\
$\mathbf{0 , 8 0 - 1 , 0 0 0}$ & Sangat Kuat \\
\hline
\end{tabular}

Sumber: Sugiyono (2007:183)

\subsection{Uji Hipotesis}

Uji t digunakan untuk menguji apakah terdapat pengaruh signifikan antara Variabel Kualitas Pembelajaran $\left(\mathrm{X}_{1}\right)$, Kualitas Tutor $\left(\mathrm{X}_{2}\right)$ Dan Motivasi Belajar $\left(\mathrm{X}_{3}\right)$, terhadap Variabel Terikat yaitu Prestasi Belajar Mahasiswa (Y). Untuk menentukan apakah hipotesis yang diajukan signifikan atau tidak, maka perlu dilihat dari estimasi t-hitung yang ditunjukan oleh tabel berikut ini :

Tabel 6. Hasil Uji Hipotesis (Uji t)

\begin{tabular}{|c|c|c|c|c|c|c|c|c|}
\hline \multicolumn{9}{|c|}{ Coefficients ${ }^{\mathrm{a}}$} \\
\hline \multirow[b]{2}{*}{ Model } & & \multicolumn{2}{|c|}{$\begin{array}{c}\text { Unstandardized } \\
\text { Coefficients }\end{array}$} & \multirow{2}{*}{$\begin{array}{c}\text { Standardized } \\
\text { Coefficients }\end{array}$} & \multirow[b]{2}{*}{$t$} & \multirow[b]{2}{*}{ Sig. } & \multicolumn{2}{|c|}{ Collinearity Statistics } \\
\hline & & B & Std. Error & & & & Tolerance & VIF \\
\hline & (Constant) & -1.649 & .771 & & -2.138 & .037 & & \\
\hline & Kualitas Pembelajaran & .567 & .102 & .532 & 5.542 & .000 & 875 & 1.143 \\
\hline & Kualitas Tutor & .351 & .114 & .296 & 3.077 & .003 & .875 & 1.143 \\
\hline & Motivasi Belajar & .457 & .143 & .291 & 3.203 & .002 & .980 & 1.021 \\
\hline
\end{tabular}

a. Dependent Variable: Prestasi Belajar Mahasiswa

Sumber: Data (diolah) SPSS

Berdasarkan tabel di atas dapat diketahui bahwa nilai $t_{\text {hitung }}$ untuk Variabel Kualitas Pembelajaran $\left(\mathrm{X}_{1}\right)$ adalah sebesar 5,542, Kualitas Tutor $\left(\mathrm{X}_{2}\right)$ adalah sebesar 3,077, dan Motivasi Belajar $\left(\mathrm{X}_{3}\right)$ adalah sebesar 3,203, jika dibandingkan dengan $\mathrm{t}_{\text {tabel }}=1,9983$. Hasil estimasi tersebut menyatakan bahwa nilai thitung ketiga variabel bebas atas variabel terikat lebih besar dari $t_{\text {tabel }}\left(t_{\text {hitung }}>t_{\text {tabel }}\right)$, maka kreteria Ha diterima dan Ho ditolak, hal ini berarti ketiga variabel bebas dapat dikatakan berpengaruh signifikan terhadap variabel terikat. Disisi lain, jika dibandingkan antara nilai koefisien Sig. dengan nilai P-value $(\alpha)$ 
sebesar 0,05, maka dapat diketahui bahwa koefisien Sig. variabel $\mathrm{X}_{1}$ sebesar 0,000, koefisien Sig. variabel $X_{2}$ sebesar 0,003, koefisien Sig. variabel $X_{3}$ sebesar 0,002, ketiga variabel bebas tersebut memiliki nilai koefisien Sig. yang masih dibawah nilai P-value $(\alpha)$, hal ini berarti $\mathrm{H}_{\mathrm{a}}$ diterima dan $\mathrm{H}_{0}$ ditolak, artinya bahwa ada hubungan secara signifikan antara Variabel Kualitas Pembelajaran $\left(\mathrm{X}_{1}\right)$, Kualitas Tutor $\left(\mathrm{X}_{2}\right)$ Dan Motivasi Belajar $\left(\mathrm{X}_{3}\right)$, terhadap Variabel Terikat yaitu Prestasi Belajar Mahasiswa (Y).

Uji F (F-test). Hasil analisis data dengan menggunakan program SPSS For Windows Relase 15.00 dapat disajikan dalam tabel berikut:

Tabel 7. Hasil Estimasi uji F

ANOVA $^{\text {b }}$

\begin{tabular}{|ll|r|r|r|r|r|}
\hline Model & & $\begin{array}{c}\text { Sum of } \\
\text { Squares }\end{array}$ & df & Mean Square & F & Sig. \\
\hline 1 & Regression & 35.944 & 3 & 11.981 & 20.949 & $.000^{a}$ \\
& Residual & 34.888 & 61 & .572 & & \\
& Total & 70.832 & 64 & & & \\
\hline
\end{tabular}

a. Predictors: (Constant), Motivasi Belajar, Kualitas Tutor, Kualitas Pembelajaran

b. Dependent Variable: Prestasi Belajar Mahasiswa

Sumber : Hasil olah data primer

Dari tabel di atas, diketahui nilai $\mathrm{F}_{\text {hitung }}$ sebesar 20,949 > nilai $\mathrm{F}_{\text {tabel }}$ sebesar 2,7554 dan dikuatkan dengan nilai koefisien sig. $F_{\text {hitung }}$ sebesar $0,000<\mathrm{P}$-value $(\alpha)$ sebesar 0,05 . Berdasarkan kriteria pengujiannya adalah jika nilai koefisien sig. $\mathrm{F}<\mathrm{P}$-value $(\alpha)$ sebesar 0,05 berarti $\mathrm{H}_{\mathrm{a}}$ diterima dan $\mathrm{H}_{\mathrm{o}}$ ditolak. Maka dapat disimpulkan bahwa bahwa ada hubungan secara signifikan antara Variabel Kualitas Pembelajaran $\left(\mathrm{X}_{1}\right)$, Kualitas Tutor $\left(\mathrm{X}_{2}\right)$ dan Motivasi Belajar $\left(\mathrm{X}_{3}\right)$, terhadap Variabel Terikat yaitu Prestasi Belajar Mahasiswa (Y).

\section{Kesimpulan}

Hasil dari perhitungan keseluruhan bahwa kualitas pembelajaran, kualitas tutor dan motivasi berpengaruh signifikan secara bersama-sama terhadap prestasi belajar mahasiswa Universitas Terbuka Palembang (Pokjar Pangkalan Lampam - Tulung Selapan). Kualitas pembelajaran secara parsial berpengaruh signifikan terhadap prestasi belajar mahasiswa Universitas Terbuka Palembang (Pokjar Pangkalan Lampam - Tulung Selapan). Kualitas tutor secara parsial berpengaruh signifikan terhadap prestasi belajar mahasiswa Universitas Terbuka Palembang (Pokjar Pangkalan Lampam - Tulung Selapan). Dan motivasi secara parsial berpengaruh signifikan terhadap prestasi belajar mahasiswa Universitas Terbuka Palembang (Pokjar Pangkalan Lampam - Tulung Selapan), serta kualitas pembelajaran menjadi faktor dominan yang mempengaruhi prestasi belajar mahasiswa Universitas Terbuka Palembang (Pokjar Pangkalan Lampam - Tulung Selapan). SARAN, pertama, perlu di pertahankan Kualitas pembelajaran yang telah diterapkan, untuk tetap memacu prestasi belajar mahasiswa Universitas Terbuka Palembang (Pokjar Pangkalan Lampam - Tulung Selapan). Dua, Kualitas tutor dan motivasi belajar mahasiswa perlu ditingkatkan, agar prestasi belajar mahasiswa meningkat juga. Ketiga, Peneliti selanjutnya dapat memilih variabel lain yang berhubungan dengan prestasi belajar, serta penelitian ini sebagai pembanding.

\section{Referensi}


Afandi, M., Chamalah, E., \& Oktarina, P.W. (2013). Model dan Metode Pembelajaran di Sekolah. Semarang: Unissila Press..

Aziz. (2018). Kontribusi lingkungan belajar dan proses pembelajaran terhadap prestasi belajar siswa di sekolah. Jurnal Tarbiyah 25(2).

Dimyati., \& Mudjiono. (2012). Belajar dan Pembelajaran. Jakarta: PT Rineka Cipta

Dwi., \& Puryanto. (2015). Pengaruh kualitas fasilitas, kualitas pembelajaran dan lokasi terhadap keputusan memilih jasa pendidikan di smpit global insani islamic schoolbekasi. Jurnal Ekonomi dan Bisnis STIE YPN 8(3).

Dwipurwani. (2012). Faktor-faktor yang Mempengaruhi Prestasi Mahasiswa Ditinjau dari Karakteristik Lingkungan Kampus (Studi Kasus di Jurusan Matematika FMIPA Unsri). Jurnal penelitian sains, 15 (1) :1-5.

Isman, S. \& Djoko, S. B. (2014). Pengaruh Pembelajaran Model Tutorial Tatap Muka Terhadap Prestasi Akademik Mahasiswa Program S1 Pendas Kabupaten Rembang Upbjj-Ut Semarang Masa Registerasi 2014.1

Maesaroh., \& Siti. (2013). Peranan Metode Pembelajaran Terhadap Minat Dan Prestasi Belajar Pendidikan Agama Islam. Jurnal Kependidikan, 1(1).

Mulyasa, E. (2013). Kurikulum Berbasis Kompetensi.Bandung:Remaja Rosdakarya.

Rahman., \& Nazarudin. (2015). Pengantar Manajemen Kurikulum. Palembang: NoerFikri Offset.

Sandu, S. \& Ali, S. (2015). Dasar Metodologi Penelitian. Yogyakarta: Literasi Media Publishing.

Sardiman, A.M. (2016). Interaksi dan Motivasi Belajar Mengajar.Jakarta: Raja Grafindo Persada

Sugiyono. (2015). Metode Penelitian Pendidikan (Pendekatan Kuantitatif, Kualitatif, dan $R \& D)$. Bandung: Alfabeta.

Umar., \& Husein. (2019). Metode Riset Manajemen Perusahaan, Langkah Cepat dan Tepat Menyusun Tesis dan Disertasi. Jakarta: Gramedia Pustaka Utama.

Zalma, S., \& Maria, V. R. (2020). Kompetensi tutor dan kualitas pembelajaran di lembaga kursus English is friend Surabaya. Jurnal Pendidikan untuk semua 4(1).

\section{Copyrights}

Copyright for this article is retained by the author(s), with first publication rights granted to the journal.

This is an open-access article distributed under the terms and conditions of the Creative Commons Attribution license (http://creativecommons.org/licenses/by/4.0/) 